\title{
Hermione Granger's Act of Equality in Harry Potter Saga Movies
}

\author{
Aprinus Salam \\ Universitas Gadjah Mada \\ Yogyakarta, Indonesia \\ aprinus@ugm.ac.id
}

\author{
Ninies Aini Fitria Dewi \\ Universitas Gadjah Mada \\ Yogyakarta, Indonesia \\ nafitiadewi@gmail.com
}

\begin{abstract}
The present research tries to describe the distribution of the sensible based on Jacques Ranciere's perspectives in Harry Potter Saga. The term distribution of the sensible is firsly proposed by Ranciere which gives attention to how the subject is placed in a certain position of the social structure. The description about politics domain and literature domain will be explained in this research along with some additional data such as dialogues and scenes from the movies. This research will be done through some stages; starting from collecting the data, classifying the data, processing the data, and describing the whole data into paragraph. The main subject who will be described in this research is Hermione Granger, a girl who comes from an ordinary little family (mud blood) and was choosen to become a student in Hogwarts Magic School. The conflict between stereotype of that school of wizard only exists for pure blood becomes the conflict occurred in the police. This research elaborates the position of the subject in a social structure and the action in which the subject does reach the equality in Harry Potter Saga by considering the aspects of action, thought, and feeling. The result shows that the distribution of the sensible in Harry Potter Saga is based on the social structure. The differences of social classes are also explained by the actors and actresses in the whole movies based on the purity of the blood (pure blood, half blood, and mud blood). Hermione Granger as the subject succeed in doing the act of equality within social hierarchy by keeping herself present in the classrom with other friends. $n$ addition, subject dares to do the resistance through Draco Malfoy (pure blood wizard) and Lav (half blood witch).
\end{abstract}

Keywords-subject, the act of equalism, social structure, movie

\section{INTRODUCTION}

The literary work that is used as an object of study is Harry Potter Saga film. Before being converted into a film, the story of a talented wizard at the Hogwarts School of Witchcraft was written by J. K. Rowling in the form of novel consisting of seven series. These works were written by Rowling in the span of 1997 to 2007. Until a production house was interested in taking the story into film. The seven films in question include Harry Potter and The Philosopher's Stone [3], Harry Potter and The Chamber of Secrets [4], Harry Potter and The Prisoner of Azkaban [1], Harry Potter and The Goblet of Fire [17], Harry Potter and The Order of the Phoenix [6], Harry Potter and the Half-Blood Prince [7], Harry Potter and The Deathly Hallows Part 1 [8] and Harry Potter and The Deathly Hallows Part 2 [9]. Like the novels, the seven Harry Potter series won the attention of audiences and won many awards.
As a form of transfer vehicle, the seven Harry Potter series have the same story concept with the novel. With respect to Klarer's [16], film belongs to the type of literary work. Klarer [16] gives a discussion of film in textual studies in more detail in An Introduction to Literary Studies. According to him, despite having its own terminology, the forms presented in the film are adaptations of literary text features and this can be explained in a textual framework. Film as a work contains important points of the underlying literary text and then presents it to the audience in a visual form.

The subject of this paper is Hermione Granger, a friend of Harry Potter and Ron Weasley. Hermione is the daughter of Mr. Hector-Dagworth Granger and Mrs. Granger who works as a dentist. Hermione is a magician who does not have pure blood or in other words Hermione's family is an ordinary one and has never been touched by magical things. Hermione is different from her two best friends, Harry Potter and Ron Weasley, whose parents are magicians. Nevertheless, Hermione is explained as a clever and a critical student.

Through this article, we will explain the problems that arise in the police and the actions taken by Hermione as subjects to oppose the police and undermine the dominant structure. There are other things to verify the intended act of equality, namely by paying attention to aspects of the subject's behavior, thoughts and feelings. Therefore, Ranciere's view of equality is applied to process data from the Harry Potter Saga film. As for the data presented in the form of dialogue quotations and scene depictions, they are represented in the forms of actions taken by the subjects in the Harry Potter Saga movie.

The concept of distribution of sensible was introduced by Jacques Ranciere, a professor of philosophy in Switzerland and emeritus professor in France. Although now retired, Ranciere is still actively giving public lectures as a visiting professor at several universities outside France, such as Harvard, Rutgers, John Hopkins, and Berkeley ([14]; [12]; [13]; [10]; [2]). His thinking about the distribution of sensible plays an important role in the study of philosophy that criticizes the aripipolitic, parapolitic, and metapolitic views put forward by Plato, Aristotle, and Karl Marx. When criticizing Plato, for example, if the division of society is only based on certain roles, it will be possible to override the ability of others to perform the same role ([12]; [15]; [2]). 
Departing from this, Ranciere then stated that if the concept is used in the division of society, it will only give birth to injustice. The distribution of subjects based on certain roles is called regulated by the police. The term is ultimately the root of the formation of social hierarchy in society. The view of the subject in a social structure always rests on the capabilities it has in a particular field. The subject's ability to perform his role becomes a tool of full legitimacy in class determination in social structures ([13]; [2]; [5]).

Distribution of the sensible is then divided into two parts, namely the political domain and the literary domain. The political domain in Ranciere's view consists of the police and politics, while the literary domain is divided into ethical regimes, representational regimes, and aesthetic regimes of art. Fill politics refers to the reaction shown by the subject in opposing the police. In his book, [11] argues that politics is not the use of power and should be defined in its own terms as a particular way of acting on the subject and its actions. The police are social structures that divide people on the basis of their respective qualifications. The police is defined as a regulatory system that builds a distribution of sensible that divides subjects into different groups or positions.

Politics and the police are two different things, but the two can meet in the intermediate space. Meeting in the intermediate space which in Bhabha's term is called as the liminal space is a strategy to unite the two. However, both politics and the police can only meet without ever being united because there will always be conflicts issued by politics to fight the police order. The conflict between politics and the police is actually to achieve equality that can only be done if the subject already feels that he is equal to other subjects. This is in line with the desire achieved by the subject to tear down the dominant structure. Equality in Ranciere's perspective is intellectual equality which means that every subject has the same ability to think.

The discussion about equality actions was also conveyed by Ranciere through the character of Jacob Jacotot in The Ignorat Schoolmaster [12]. In a book describing the practice of pedagogy, Ranciere also commented on four black students sitting in the cafeteria with other white students. Although physically "viewed differently", the four students still sit in the cafeteria like students in general. In these four students, their mindset has been implanted that they are equal to other students without having to fight or write a statement to the school. They have achieved equality by acting as equals as other students; sitting in the cafeteria freely ([12]; [15]).

As has mentioned earlier, in the literary domain Ranciere divided it into three regimes namely: the ethical regime; the regime of representation; and the aesthetic regime of art. An ethical regime is analogous to a regime that views a literary work as a reflection of the society within it ([12]; [13]). The representation regime sees literary works as representations of human action. In Ranciere's view, in the representation regime, many literary works are actually trapped resulting in stereotypes in the lives of the people. This then results in the subject being able to represent good-bad stereotypes in accordance with what has been developed in society. Meanwhile, the aesthetic regime of art for Ranciere saw criticism no longer on the 'what' discussed in literary works, but 'how' the subjects in the work were expressed ([12];[13];[15]).

\section{THE POLICE IN HARRY POTTER SAGA}

In Harry Potter series, there is a social structure that describes classes of magicians who are grouped based on the purity of their blood. A magician can come from a family of magicians (pure blood), a mixed family (half blood), and an ordinary family (muggle or also called mud blood). The police groups the witches by family descent. This then gave birth to a dominant class in the social structure of the story. Pure-blooded witches or pure blood dominate the order of the police and cause half-blooded witches and mud-blooded witches to be marginalized.

Hermione Granger, though a magician, is herself a muggle or mud blood. His parents, Mr. Hector-Dagworth Granger and Mrs. Granger are ordinary people who work as dentists. Hermione's father and mother are not witches and there is no any blood of this kind flowing in her family. Hermione was the first person in her family to have a magical talent and was finally selected by Hogwarts School to be their student. Each student who has received a letter of acceptance for new students from Hogwarts School will travel to a world of magic that is different from the world of humans in general. Students will be selected to enter a designated dormitory before finally studying at Hogwarts School.

Hogwarts School was founded by four great magicians of their time, namely Godric Griffyndor, Helga Hufflepuff, Rowena Ravenclaw, and Salazar Slytherin. They founded Hogwarts School with the aim of accommodating talented magicians in order to maximize their abilities. Hogwarts School was deliberately set up in a location very far from the residence of the Muggles because, at that time, magic was feared by most humans and caused the magicians to get a lot of torture. This can be traced through the setting of Hogwarts School, which is in the middle of nowhere, surrounded by forests, rivers and hills. In the film Harry Potter and The Philosopher's Stone [3], it is mentioned how Harry Potter and Ron Weasley must penetrate platform $93 / 4$ at the train station to get to Hogwarts School.

The four witches who founded the Hogwarts School, Salazar Slytherin had a different view from other wizards, specifically the view of muggles. According to Slytherin, only pure-blooded wizards were allowed to attend Hogwarts School. Slytherin wanted that the teaching of witchcraft was only for the wizarding family. According to Slytherin, muggle-born witches or ordinary human descendants should not be trusted. However, due to the policies issued by Griffyndor, Hufflepuff, and Ravenclaw, the half blood magicians and mud blood magicians were still allowed to study at Hogwarts School. The names of the four wizards were later enshrined to be the name of a hostel at Hogwarts School.

Departing from this, the view of pure-blooded wizards became increasingly dominant. The descendants of Slytherin who attend Hogwarts School always dominate other wizard classes. Students who are half blood and mud blood are always marginalized. One scene that represents the dominance of pure blood over mud blood is the scene when Draco Malfoy called 
Hermione the "mud blood" after class. Draco Malfoy was Hermione's classmate, Harry, and Ron who were from the Slytherin dormitory. Malfoy is a descendant of Slytherin and all members of his family are pure blood wizards. Because of the dominance of pure blood over mud blood at Hogwarts School, Hermione became one of the marginalized subject.

$\begin{array}{lcl}\text { Hermione } & : & \text { "He called me mud blood." } \\ \text { Harry } & : & \text { "What is mud blood?" } \\ \text { Hermione } \quad: & \text { "It means "dirty blood". Mud }\end{array}$
blood is a really foul name for someone who's muggle-born. Someone with nonmagic parents. Someone like me.”

([4] : 00.46.26-00.46.39)

Through the excerpt above, it is known that there is a strong dominance in Malfoy as a student who comes from the descendants of pure magicians. The term "mud blood" pinned by Malfoy to Hermione was a mockery that was commonly leveled at someone born into a family of muggles. The ridicule is an evidence of the dominance of the police system at Hogwarts School. In this case, the order of the police in Harry Potter Saga film acts to divide the subject based on the purity of the blood of magicians. Malfoy as a pure-blooded magician was placed as a subject in a higher position than Hermione. This domination made Hermione's position as the subject in a marginalized position.

The existence of strong dominance in pure-blooded magicians can also be noticed through events that occur in Harry Potter and The Goblet of Fire (2005) [17]. In the film, there is a scene between Draco Malfoy's family and Ron Weasley's family who was with Harry Potter. In the scene, the two families meet in the stands to watch the most prestigious Quidditch match in the wizarding world. The Malfoys sit in the most strategic seats because for families of pure-blooded magicians get a special invitation from the Ministry of Magic, while mixed-blooded families do not get the invitation so they have to sit in the uppermost stands. Because the Ron Weasleys came together with Harry Potter, who was a mixed-blood wizard, they had to sit on the top seat in the stands.

Malfoy :"Well, put it this way. If it is rain, you will be the first to know!”

$$
\text { ([17]2005: 00.07.45-00.07.49) }
$$

The quote above is a mockery spoken by Draco Malfoy to Harry Potter as a form of ridicule because he got a spectator seat at the top of the stands while he got a seat in the middle with the most strategic visibility. The mockery spoken by Malfoy as a wizard in the order of the police is in the highest class shows his dominance over Harry Potter as a subject in the lower class (half blood). This supports the previous statement that the police order in Harry Potter Saga classifies wizard classes based on blood purity. Malfoy and his family as pureblooded magicians find it easy to access Quidditch matches until he and his family get a special invitation to be able to sit in the strategic audience seats. Meanwhile, Harry Potter who is a mixed-blooded wizard must accept that in the order of the police, he did not get easy access to choose a seat in a strategic area such as Malfoy and his family. Harry must be willing to sit in the uppermost seats of the stands along with other nonpure-blooded witches.

\section{HERMIONE GRANGER'S ACT OF EQUALITY IN HARRY POTTER SAGA}

In the order of the police, when the subject succeeded in carrying out political action on the conflict that occurred, then the subject succeeded in breaking down the dominant system. This is of course with a note that the subject must already be intellectually considering himself to be on a par with other subjects in the police order. The equality action carried out by the subject is carried out in order to achieve equality itself.

In Harry Potter Saga film, Hermione Granger is called the "mud blood" because of the impurity of the blood of wizards in her family. However, as a subject, Hermione did not fight Malfoy who in the order of the police was in a more dominant position. Hermione continued to go to school and go to class as usual with other friends even though Malfoy often mocked her as mud blood. While in class, Hermione often answers the questions of her teacher and the answers are always correct. Some scenes recorded include 00.54.39 minutes, 01.10.21 (2001) [3], 00.36.02 minutes, 00.41 .39 (2002) [4], 00.40.33 minutes, 00.52.40 (2004) [1], and minutes 00.35.04 (2009) [7].

By paying attention to the attitudes displayed by the Hermione's character in Harry Potter Saga movie, it is found that Hermione as the subject is trying to undermine the dominant structure in the police. The subject tried to achieve equality that she was also a magician with good abilities by positioning herself on a par with his classmates who were mixed-blooded and pure-blooded magicians. Subjects without feeling reluctant to mingle and interact with their friends without feeling that he is not included in the "pure blood magic group". In the subject, the thought is embedded that all students who are accepted at Hogwarts School have the same intellectual ability to learn from each other and discuss with each other.

In the film Harry Potter and The Order of the Phoenix (2007) [6], there are scenes where Harry Potter, Hermione Granger, Ron Weasley and other friends are looking for a room to practice magic. In the search, Neville Longbottom, one of Harry's friends, Hermione, and Ron managed to find a Room of Requirement on the side of Hogwarts School that was hidden and difficult to reach by other students and teachers. At first, Neville did not know what kind of room he had found that was out of the blue. However, thanks to Hermione's cleverness that was shown as a studious student, Neville and other friends finally knew that the room was the Room of Requirement. The Room of Requirement will only appear when it is actually searched, even the room can be adjusted according to its search.

\section{Hermione : "You've done it, Neville. You found the Room of Requirement."}

Neville :"What?” 


\begin{abstract}
Hermione : "It's also known as Come and Go Room. The Room of Requirement only appears when a person has a need of it. And it always equips the seeker.”
\end{abstract}

$$
\text { ([3] 2002: 00.58.18-00.58.32) }
$$

Of all Hermione's friends, no one knew what the Room of Requirement was except Hermione. Harry Potter did not even know about the Room of Requirement at Hogwarts School. Harry Potter who, if seen as a subject, he is a mixed-blood wizard because his mother's family is muggles or ordinary people. However, it turns out that for a mixed-blooded wizard like Harry Potter, he had no knowledge of the Room of Requirement. Besides that, Ron Weasley who came from a pure blooded witch also did not know about the Room of Requirement. This indicates that the character of Hermione actually has a higher intellectual level when compared to her friends who belong to the group of mixed-blooded and pureblooded magicians.

If you pay attention to some scenes when Hermione is actively studying and often reads books, it appears that she has a deeper sense of magic. Even though Hermione's parents were not magicians and there was no blood flowing inside her, Hermione had a talent for witchcraft. Long before Hermione entered the classroom and learned magic using spells, she had mastered a few simple spells. Hermione's feelings towards witchcraft led her to be the best wizard student in the class, even other figures such as Rubeus Hagrid who was the guardian of Hogwarts School and pure-blooded witches also justified Hermione's magical talents

Hagrid : "And it's codswallop to boot dirty blood. Why there isn't wizard alive today that's not half-blood or less. More to point, they've yet to think of a spell that our Hermione can't do."

$$
\text { ([4] 2002: 00.46.57-00.47.07) }
$$

Hagrid said that mixed-blooded wizards and muggleblooded mages also had the same abilities as pure-blooded mages. The statement made by Hagrid in the order of the police is equivalent to Malfoy because both pure-blooded magicians are considered important to underline. This implies that the ability possessed by Hermione as a subject who is in a marginalized position in the order of the police is equal and is even recognized by Hagrid as a subject with a higher and dominant position.

Not only Hagrid, the confession that came from pureblooded magicians to Hermione was also revealed by Sirius Black. Based on the film of Harry Potter and The Prisoner of Azkaban (2004) [1], Sirius Black is Harry Potter's godfather. The Black Family is a family of pure blood magicians. In the family tree displayed in the Harry Potter and The Prisoner of Azkaban (2004) [1] movie scenes, all members of the Black family are magicians. Although coming from a class of magicians who have a more dominant position, Black acknowledged Hermione's ability in the police order to be in a lower position. According to Black, seeing as Hermione's very young age, he assumed that Hermione was the most powerful female magician, as stated in the quote below.

Black :"You really are the brightest witch of your age I've
ever met."

$$
\text { ([1] 2004: 01.23.08-01.23.12) }
$$

Hermione also has a mind as a magician who is reliable in dealing with obstacles. One proof is when she first met with Ron Weasley and Harry Potter on the train to Hogwarts School. Harry's glasses are broken and Hermione is also doing magic at the moment to fix it. With the right spell, Hermione was able to fix Harry's glasses. This shows that the character of Hermione as a subject has a mind as a magician. She is able to think practically and chooses the right spell to use at the time.

Furthermore, in the film Harry Potter and The Order of the Phoenix (2007) [6], when Harry Potter, Hermione Granger and Ron Weasley had just heard from Sirius Black that Lord Voldemort had returned and wanted revenge, Hermione invited her friends to practice defend against Lord Voldermot's attacks. Lord Voldermort is the most feared wizard in Harry Potter Saga story. Voldemort is often referred to as "The Dark Lord" which means 'witch of black magic'. It is said that Voldemort had prepared his followers to carry out attacks on Harry Potter and the Hogwarts School. Realizing that bad events were about to happen, Hermione instinctively asked Harry Potter and Ron Weasley to defend themselves from the attacks of The Dark Lord.

Hermione :"He’s really out there, isn't he? We’ve got be able to defend ourselves."

$$
\text { ([6] 2007: 00.52.40-00.52.46) }
$$

Hermione then invited her friends to find a room to serve as a place to practice magic. The spirit to practice magic in order to prepare themselves to defend against Lord Voldemort was brought by the character of Hermione. This indicates that Hermione had the courage to face Lord Voldemort, the most feared wizard in the wizarding world. The spirit to practice using defensive spells that have been learned actually comes from a wizard descended from muggles, not out of the mouth of Harry Potter or Ron Weasley though. As a subject, Hermione had considered herself equal to Harry Potter, because in Harry Potter Saga, there was a prediction that the one who was able to defeat Lord Voldemort was only Harry Potter. However, seeing the courage displayed through Hermione's statement in the previous quotation, it is meant that Hermione directly considered herself equal because she also dared to oppose Lord Voldemort.

The courage displayed by the character of Hermione also appears in the Harry Potter and The Prisoner of Azkaban (2004) [1]. In one of the scenes in the third film series, the character Malfoy and his friends are mocking one of the school's magical beasts who will be sentenced to death. The animal is a buk-beak and is one of Hagrid's favorite animals, guards at Hogwarts School. In the scene, Malfoy tells his friends that after the buck beak is decapitated, the buck beak 
head will be hung in front of the entrance to Gryffindor. When Malfoy was making fun of buck beak with his friends, Hermione, Harry, and Ron who heard them are approaching from a distance. Suddenly, Hermione hurried over to Malfoy and punched him in the face while delivering a curse.

\section{Hermione : "You! You foul, loathsome, evil, little cockroach!”}

([6] 2007: 01.23.18-01.23.20)

The actions taken by Hermione can be classified as equality when seen from Ranciere's perspective. Even though Hermione had been cursed by Malfoy as "mud blood" and mocked his parents as "muggles", she did not become inferior and hated the fate that she was born as a wizard descended from muggles. Hermione actually became a brave woman and was able to show her point of equality before Malfoy, who in the order of the police had a dominant position towards him. Hermione's spontaneous actions immediately showed Malfoy that they were in an equal position.

In addition to the events mentioned earlier, Hermione also performed quite bold actions on Lav in Harry Potter and The Half-Blood Prince (2009) [7] film. In one scene, Ron is told to have been successfully recruited by the Quidditch Hogwarst School team and joined the team along with Harry Potter. When Ron had an accident due to being poisoned by the opposing team while competing in Quidditch, both Hermione and Lav came to the school hospital to see Ron's condition. When Lav asked what had happened to her lover, he instead added a statement that Hermione had deliberately snatched Ron by pretending to be Ron's best friend. When Hermione received the accusation by Lav, she boldly cursed and called Lav "stupid" because the statement she issued did not relate to the facts that actually happened.

\section{Hermione : :He has been poisoned, you duff dumb!”}

$$
\text { ([6] 2007: 01.32.16-01.32.18) }
$$

The remark spoken by Hermione to Lav was a form of equality she did. Hermione felt that she was equal to Lav who was a mixed blood witch. This means that Lav's position in the police order is higher and more dominant than Hermione's. Because the statement Lav said had no connection and offended Hermione, she also dared to take action against the dominant structure. Even though Hermione was not from a family of pure blood magicians, but she dared to fight Lav who was a witch in a half blood type.

The action taken by Hermione was similar to what happened when Malfoy mocked Hermione as "mud blood". Hermione's courage to punch Malfoy's face and rebuke Lav was a form of equality in order to undermine the dominant structure that muggle-born mages were inferior to mixedblooded and pure-blooded mages. The act of equality was considered successful because Hermione already considered herself to be in the same position as Draco Malfoy who was a pure blood magician and Lav, a mixed blood magician.

\section{CONCLUSION}

The above discussion explains that the police order divides classes of magicians based on blood purity. The classes are divided into three groups, namely (1) the pure-blooded witches or also called as the pure whackles, (2) the mixed-blooded wizards or also called as half blood, and (3) the witches who were born from ordinary families and do not have blood of the magician. A wizard who was born not from a family of wizards is also called as a mud blood witch and his or her parents who are human beings are commonly referred to as muggles. The formation of a dominant class based on the existence of blood leads the pure blood magician to be in the highest and most dominant position than other magicians. Meanwhile, the mud blood magicians are positioned as magicians who are in the lowest class and marginalized.

The notion that only pure-blooded wizards are allowed to study at Hogwarts School creates a conflict between the police and politics. Hermione, as the central subject discussed in this study, received less favorable treatment from Malfoy, his classmate who is a pure blood witch or pure blood. Mockery in the form of "mud blood" is often pinned on Hermione every time she meets Malfoy and his friends. Nevertheless, Hermione continued to attend school and study with other friends who were also pure-blooded and mixed-blooded wizards. With the presence of Hermione at Hogwarts School, it was already a form of equality that she did to undermine the dominant system that only the pure-blooded wizards were allowed to enter the magic school. Through Hermione's character as a subject, it is evident that magicians who are not from wizard families can learn magic at Hogwarts School. Even in the class, Hermione is shown as a student who is smart and, she masters materials well.

To achieve equality, Hermione took courageous action against Draco Malfoy who often mocked her as "mud blood" and called Hermione's parents a muggle. In one of the Harry Potter Saga films, Hermione punched Malfoy in the face. This shows that Hermione directly positioned herself on a par with Malfoy, a pure-blooded witch. In addition, Hermione also bravely rebuked Lav for issuing statements that were not in accordance with reality and accused Hermione with accusations that were not true. Hermione's courage to rebuke Lav as "stupid" is also a form of equality which is done as a subject to achieve equality .

\section{REFERENCES}

[1] A. Cuaron, Alfonso, (Sutradara), Harry Potter and The Prisoner of Azkaban. [Gambar hidup], 2004.

[2] A. Hambali, "Kesetaraan Radikal: Analisis Pemikiran Pendidikan Jacques Ranciere.” Indonesian Journal of Sociology and Education Policy, Vol.2, No.2, hlm. 1-25, 2017.

[3] C. Columbus, (Sutradara). Harry Potter and The Philosopher's Stone. [Gambar hidup], 2001

[4] C. Columbus, (Sutradara). Harry Potter and The Chamber of Secrets. [Gambar hidup], 2002. 
[5] D. Panagia, Davide. "Partage du Sensible": The Distribution of The Sensible.” in Deranty, Jean-Philippe. Jacques Rancier: Key Concept. United Kingdom: Acumen, 2010.

[6] D. Yates, (Sutradara). Harry Potter and The Order of The Phoenix. [Gambar hidup], 2007.

[7] D. Yates, (Sutradara). Harry Potter and The Half-Blood Prince. [Gambar hidup]. 2009.

[8] D. Yates, (Sutradara). Harry Potter and The Deathly Hallows Part 1. [Gambar hidup]. 2010

[9] D. Yates, (Sutradara). Harry Potter and The Deathly Hallows Part 2. [Gambar hidup]. 2011.

[10] I. Saputra, "Distribution of The Sensible dalam Novel A Time to Kill Karya John Grisham: Analisis Perspektif Rancierean”. Yogyakarta: Universitas Gadjah Mada (unpublished thesis), 2018.
[11] J. Ranciere, The Ignorant Schoolmaster: Five Lesson in Intelectual Emancipation (terjemahan Kristin Ross). California: Stanford University, 1991.

[12] J. Ranciere, The Politics of Aesthetics: The Distribution of The Sensible. New York: Continuum, 2004.

[13] J. Ranciere, Dissensus: On Politics and Aesthetics. New York: Continuum, 2010.

[14] K. Bertens, Filsafat Barat Kontemporer: Prancis. Jakarta: Gramedia Pusaka Utama, 2006.

[15] M. Al-Fayyadl, “Kritik Sastra di Prancis”. Poetika, 3 (2), pp. 143-153, 2015

[16] M. Klarer, An Introduction to Literary Studies. London: Routledge. 2004.

[17] M. Newell, (Sutradara), Harry Potter and The Goblet of Fire. [Gambar hidup], 2005. 